\title{
Home Care as a safe alternative during the COVID-19 crisis
}

\author{
(D) Heloisa Amaral Gaspar' \\ ID Cláudio Flauzino de Oliveira ${ }^{2}$ \\ (iD) Fabiana Camolesi Jacober ${ }^{3}$ \\ (iD) Eduardo Roberto de Deus ${ }^{4}$ \\ (iD) Flavia Canuto ${ }^{5}$
}

\begin{abstract}
1. Médica Intensivista Pediátrica, Doutora em Ciências pela Faculdade de Medicina da USP, Gerente Médica Home Doctor, São Paulo, Brasil. 2. Médico Intensivista Pediátrico, Doutor em Ciências pela Faculdade de Medicina da USP, Diretor Home Doctor, São Paulo, Brasil. 3. Enfermeira especialista em Controle de Infecção Domiciliar e Analista de Qualidade Home Doctor, São Paulo, Brasil.

4. Analista Sênior de Qualidade Home Doctor, São Paulo, Brasil. 5. Enfermeira especialista em Gerontologia, Gerente Comercial Home Doctor, São Paulo, Brasil.
\end{abstract}

http://dx.doi.org/10.1590/1806-9282.66.11.1482

\section{SUMMARY}

INTRODUCTION: There are several reports worldwide about the high mortality related to COVID-19 among residents of nursing homes. The worldwide concern about the safety of patients and professionals in these institutions is relevant. In Brasil, a large part of post-acute care and chronic patients is performed at home through Home Care (HC).

OBJECTIVE: This study aims to evaluate the incidence of COVID-19 in Home Care patients and the clinical outcomes of these patients; it also aims to assess the impact of the epidemic on the number of patients, new admissions, and hospitalizations.

METHODS: A descriptive study of the COVID-19 cases that affected the population in care by Home Doctor (a private company of Home Care), between the months of March 2020 and May 2020 and analysis of the total number of patients, the hospitalization and death rate in the period compared to the pre-epidemic period.

RESULTS: There were 31 confirmed cases of COVID-19, 21 of which were male, mean age 73 years. All patients had multiple comorbidities, the most prevalent were: Systemic Arterial Hypertension (54\%) and Stroke (35\%). The incidence of COVID-19 was 1\% in the studied population. There were 10 hospitalizations with 5 hospital deaths and one case of home death (lethality 19\%). Safe care was maintained, with a low death rate (0.6\%) and hospitalization (6.1\%).

CONCLUSION: Home Care is able to maintain safe care during the pandemic due to COVID-19, with a low incidence of COVID-19, low hospitalization rate, and low mortality when compared to nursing homes institutions.

\section{INTRODUCTION}

The World Health Organization (WHO) received, in December 2019, the first reports of cases of pneumonia of unknown etiology in the city of Wuhan (Hubei province, China), subsequently attributed to infections by the new betacoronavírus called SARS-CoV-2, Severe
Acute Respiratory Syndrome Coronavirus 2. On 30 January, the WHO declared it a global public health emergency, putting the whole world on alert. On 11 February, the new disease was named COVID-19. Patients infected by SARS-CoV-2 were identified in

DATE OF SUBMISSION: 27-JUn-2020

DATE OF ACCEPTANCE: 11-Jul-2020

CORRESPONDING AUTHOR: Heloisa Gaspar

Rua Capitão Franscico Teixeira Nogueira, 154, São Paulo, SP, Brasil - 05037-030

Tel: +55 1199313-3902

E-mail: heloisa.gaspar@homedoctor.com.br 
other countries, mainly in Europe, in the United States (USA), in Canada, and in Brasil. On 11 March 2020, the WHO characterized COVID-19 as a pandemic.

In Brasil, the first confirmed case of COVID-19 occurred on 26 February. On 20 March, the Ministry of Health acknowledged, through Decree No 454, the status of community transmission of COVID-19 throughout the national territory. Since then, the number of cases has grown exponentially, and currently, despite the known underreporting, the country holds the second position worldwide among countries with the greatest number of cases and deaths due to COVID-19. ${ }^{1}$

There are various reports worldwide on the high mortality related to COVID-19 among the residents of Nursing Homes, which correspond to 25\% of all deaths related to COVID-19 in the United States, and even larger percentages in some North American states and European countries (such as France and Ireland) $)^{2}$. The worldwide concern regarding the safety of patients and professionals in these institutions is entirely appropriate.

In Brasil, unlike the scenario of other countries such as the USA, a large part of post-acute care, rehabilitation and care of chronic patients are performed at home, through the home care (HC), instead of in nursing homes, both in the public sector and in complementary health. This modality includes the administration of medicines, enteral nutrition, wound dressing, rehabilitation therapies, oxygen therapy, and even more complex therapies such as parenteral nutrition and invasive and non-invasive mechanical ventilation.

\section{OBJECTIVE}

The present study aims to evaluate the incidence of COVID-19 in patients undergoing home care and the clinical outcomes of these patients; in addition, we aim to assess the impact of the epidemic on the numbers of total patients, new admissions, and hospitalizations during the initial period of the pandemic.

\section{METHODS}

This is a descriptive study that included the collection, tabulation and analysis of data on COVID-19 cases that affected a population undergoing care by Home Doctor (a private home care company), between March 2020 and May 2020, i.e., the $1^{\text {st }}$ quarter of the epidemic (1QTREPI), reporting the incidence of COVID-19 cases in this population and analyzing the clinical data and outcomes of these patients.

We analyzed the total number of patients undergoing care, the number of new cases (related and unrelated to COVID-19), as well as the rate of hospitalization and death in the 1QTREPI in comparison to January/2020, using as a reference the period pre-epidemic (REFPRE).

The data were retrieved from the electronic medical records system of the company and presented as absolute numbers $(\mathrm{N})$, frequency (\%), and mean when appropriate.

\section{RESULTS}

In the 1QTREPI, 2931 patients were treated in all home care programs. The company recorded over this period 31 confirmed COVID-19 cases, 10 of them in females and 21 in males, with a mean age of 73 years (21-95 years). All patients presented multiple comorbidities, and the most prevalent were: Systemic Arterial Hypertension in 17 cases (54\%) and sequelae from strokes in 11 cases (35\%). The incidence of COVID-19 was $1 \%$ in the population studied. There were 10 hospitalizations with 5 in-hospital deaths and one case of death at home, a patient undergoing exclusive palliative care, which represents a mortality rate of $19 \%$ (Table 1).

The geographical distribution of confirmed COVID19 cases was disclosed on a daily basis for the entire care team through a case map, and data relating to 31/05 are presented in Figure 1.

Virtual consultations have been made available with doctors, nurses, nutritionists, psychologists and social workers since April/2020 aiming to reduce the commuting of professionals to patient homes and, consequently, reduce patient exposure (54\% of medical visits and $44 \%$ of nurse visits were replaced by telehealth consultations). Physiotherapy and speech therapy sessions were maintained in-person due to the profile of the need of the population. A satisfaction survey was applied in patients treated through this modality using the Net Promoter Score (NPS), with a result of 54\% (zone of quality).

Patients undergoing home care received safe and quality care, with their clinical stability maintained, which can be evidenced by a low mortality rate and a low and declining rate of hospitalization in the 1QTREPI (Table 2). 
TABLE 1. CLINICAL DATA OF PATIENTS WITH A DIAGNOSIS OF COVID-19 UNDERGOING HOME CARE

\begin{tabular}{|c|c|c|c|c|c|}
\hline Initials & Age & Gender & Program & Morbidity background & Clinical outcomes \\
\hline JSP & 85 & MEN & $\mathrm{HH}$ & CHF, DM, SAH, Arrhythmia & Hospitalization \\
\hline WGL & 45 & MEN & HA & AIDS (HIV), Nasal neoplasia with metastasis in cervical lymph nodes & Recovered \\
\hline JSPF & 78 & MEN & $\mathrm{HH}$ & Alzheimer's, SAH & Recovered \\
\hline OGM & 74 & MEN & HA & COPD & Recovered \\
\hline WAVM & 64 & MEN & $\mathrm{HA}$ & CVA, Hydrocephalus, SAH & Recovered \\
\hline FACM & 71 & MEN & $\mathrm{HH}$ & Parkinson's, Coronariopathy & Recovered \\
\hline MJPB & 91 & WOMEN & $\mathrm{HH}$ & $\mathrm{SAH}, \mathrm{CHF}, \mathrm{COPD}, \mathrm{CVA}$ & Recovered \\
\hline MLPG & 88 & WOMEN & $\mathrm{HA}$ & Parkinson's, Hypothyroidism & Recovered \\
\hline RMR & 84 & MEN & $\mathrm{HA}$ & Dementia, Chronic atrial fibrillation & Recovered \\
\hline TSP & 30 & WOMEN & $\mathrm{HH}$ & Genetic Sd (HSAN), Paced bradycardia & Recovered \\
\hline EG & 62 & MEN & $\mathrm{HH}$ & Obesity, Asthma, SAH, Hip prosthesis, PTE & Recovered \\
\hline LGP & 95 & WOMEN & $\mathrm{HH}$ & Alzheimer's, SAH, CVA & Recovered \\
\hline SF & 90 & MEN & $\mathrm{HA}$ & Parkinson's, Hypothyroidism & Recovered \\
\hline FJGM & 57 & MEN & $\mathrm{HA}$ & CVA, SAH, Obstructive sleep apnea & Recovered \\
\hline AJAL & 71 & MEN & $\mathrm{HA}$ & CVA, Sigmoid volvulus, SAH & Death at home \\
\hline NRG & 93 & WOMEN & $\mathrm{HH}$ & Dementia+ DM + SAH + AMI + CHF + CKD & In-hospital death \\
\hline JGA & 74 & MEN & $\mathrm{HH}$ & COPD, DM & In-hospital death \\
\hline HAT & 90 & MEN & $\mathrm{HA}$ & CVA, Dementia, DM type II, SAH & In-hospital death \\
\hline NB & 77 & WOMEN & $\mathrm{HH}$ & Aortic aneurysm, CVA, Hypothyroidism. & In-hospital death \\
\hline MBL & 91 & WOMEN & $\mathrm{HA}$ & CVA, Thrombophilia, Lower limb arterial thrombosis, PTE, COPD, SAH, DM & In-hospital death \\
\hline HT & 82 & MEN & $\mathrm{HH}$ & SAH, Dementia, Parkinson disease, CVA & Recovered \\
\hline ASVC & 85 & WOMEN & HA & $\mathrm{SAH}, \mathrm{CHF}$, Parkinson disease & Recovered \\
\hline MJPB & 86 & MEN & $\mathrm{HH}$ & SAH, Coronariopathy, CKD & Recovered \\
\hline IRM & 83 & MEN & HA & Alzheimer's disease & In treatment \\
\hline RVPS & 40 & MEN & $\mathrm{HA}$ & TBI + Chemical dependency (cocaine) & Recovered \\
\hline LPL & 85 & WOMEN & $\mathrm{HH}$ & Obesity, SAH, DM & Hospitalization \\
\hline REM & 42 & MEN & $\mathrm{HA}$ & Epilepsy, CNPE & Hospitalization \\
\hline LASR & 21 & MEN & HA & CNPE + DM + SAH + Asthma & In treatment \\
\hline RMF & 75 & MEN & $\mathrm{HH}$ & Obesity, SAH, CVA, Polyneuropathy & In treatment \\
\hline LBLS & 84 & WOMEN & $\mathrm{HH}$ & $\mathrm{DM}$ & In treatment \\
\hline MGS & 79 & MEN & HA & SAH, Coronariopathy, CVA & Hospitalization \\
\hline
\end{tabular}

HH: Home Hospitalization, HA: Home Attendance; CHF: Congestive Heart Failure; DM: Diabetes Mellitus; SAH: Systemic arterial hypertension; AIDS: Acquired immunodeficiency syndrome; COPD: Chronic obstructive pulmonary disease; CVA: Cerebrovascular accident; PTE: Pulmonary thromboembolism; CKD: Chronic kidney disease; TBI: Traumatic brain injury; and CNPE: Chronic non-progressive encephalopathy.

FIGURE 1. CASE MAP AND GEOGRAPHICAL DISTRIBUTION

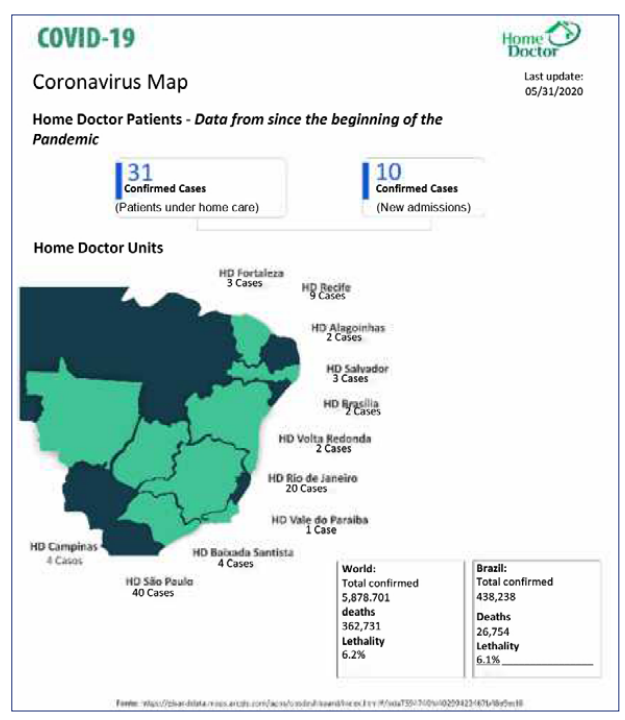

TABLE 2. NUMBER OF PATIENTS, HOSPITALIZATION RATE, AND DEATH RATE OF PATIENTS UNDERGOING HOME CARE IN THE PREEPI AND 1QTREPI PERIODS

\begin{tabular}{l|l|l|l|l|l}
$\begin{array}{l}\text { Home Doctor } \\
\text { Group }\end{array}$ & Jan/20 & Feb/20 & Mar/20 & Apr/20 & May/20 \\
\hline $\begin{array}{l}\text { Number of } \\
\text { patients }\end{array}$ & 1974 & 2033 & 2115 & 2213 & 2279 \\
\hline $\begin{array}{l}\text { Hospitalization } \\
\text { rate }\end{array}$ & $11.00 \%$ & $9.30 \%$ & $8.80 \%$ & $6.90 \%$ & $6.10 \%$ \\
\hline Death rate & $0.60 \%$ & $0.60 \%$ & $0.60 \%$ & $0.32 \%$ & $0.60 \%$ \\
\hline
\end{tabular}

From January to May, we observed an increase of 305 patients/month in home care, which represented an increase of $15 \%$ in cases treated (Table 2). This increase in patients can be attributed to:

I - Hospital discharge of COVID-19 patients, either in an active stable phase of the disease or in the rehabilitation phase 
During the 1QTREPI, a total of 35 patients were admitted into home care, from a hospital, with a diagnosis of COVID-19, 11 (32\%) of them still in the active acute phase of the disease, and 24 (68\%) for rehabilitation therapy and treatment of complications.

II - Hospital discharge of with diagnoses unrelated to COVID-19

During the 1QTREPI, 1137 patients were admitted to home care from hospitals. The main reasons for home care were the need for end of treatment with intravenous, intramuscular or subcutaneous medication, oxygen therapy, dressings, nutritional support, and rehabilitation therapies.

III- To avoid hospitalization of suspected or confirmed non-critical cases of COVID-19, through home monitoring of oximetry, oxygen supplementation, medical follow-up at home, daily medical telephone monitoring, and emergency medical center available 24/7.

In the 1QTREPI, a total of 76 patients were monitored with confirmed or suspected COVID-19, with 10 hospitalizations (13\%).

\section{DISCUSSION}

The home care sector grew exponentially in recent decades. Currently, it is estimated that approximately 1 million patients start home treatment yearly in Brasil, including the public and private sectors ${ }^{3.4}$. Thus, this segment is responsible for reducing the demand for hospital beds and the overload of the hospital sector, something that becomes even more important in the context of the COVID-19 epidemic.

Advanced age and the presence of comorbidities are associated with increased mortality in the pandemic caused by the novel coronavirus. The high prevalence of this combination, associated with physical environments that provide inadequate barriers for infection control, puts nursing home patients at great risk, and studies have shown that once a first case occurs in these institutions, the ability of the infection to spread to other patients is quite high ${ }^{5,6,7}$. The world literature reveals alarming numbers regarding these institutions, with $2 / 3$ of patients affected in a period of 3 weeks and mortality rates reaching values as high as $72 \%{ }^{8}$.

Home care, which is classically recognized by the social benefits it provides, such as patient participation in family life and society and consequent improvement in the quality of life, presents a unique advantage in terms of patient safety and infection control. The patient is naturally maintained in home isolation, assisted by a team of professionals trained to meet the special need of their care. This, in association with the correct use of individual protection equipment (IPE) and incorporation of innovations in the sector (such as the use of telehealth) are key points for safe healthcare in the context of the epidemic ${ }^{9,10,11}$.

The study population consisted primarily of elderly patients with comorbidities, and in this known risk group, the incidence of COVID-19 was of only $1 \%$. The subgroup of patients affected by COVID-19 was $80 \%$ comprised of elderly individuals, all of them with comorbidities, and the mortality of $19 \%$ observed is quite lower than that reported worldwide in nursing homes.

The epidemic drove the rapid incorporation of telehealth in the context of home care, with patient satisfaction within the quality level set by the NPS. Learning about this technology, its risks and benefits, will be essential so that professional councils and societies can define the role of this tool in the future.

Home care, like all health sectors in Brasil and worldwide, faced difficulties with the emergence of the epidemic regarding the supply chain (with scarcity and overpricin), interruption or reduction of public transport that hindered the commuting of professionals, increased rate of absenteeism, need for collaborator leaves, among others. However, it showed great plasticity and the ability to adapt, quickly and effectively re-structuring itself and being able to keep patients safe in their homes while actively contributing to keeping hospital beds available.

\section{CONCLUSION}

Home care has proven to be able to treat patients of different complexities in their home environment safely during the COVID-19 pandemic, with a low incidence of COVID-19, low hospitalization rates, and low mortality when compared to nursing homes.

Home care, in addition to maintaining patients safely in their households, is capable of increasing its capacity rapidly, admitting patients from hospital environments and contributing to improve the availability of hospital beds.

The current pandemic has led to great considerations on how to provide the best health care and create safe treatment options beyond the hospital environment. The migration of post-acute and chronic care to the home environment with the use of technology seems to be an important piece to solve this complex puzzle. 


\section{RESUMO}

INTRODUÇÃO: Diversos são os relatos mundiais a respeito da elevada mortalidade relacionada a COVID-19 entre os residentes de instituições de longa permanência. A preocupação demonstrada mundialmente sobre a segurança dos pacientes e profissionais nestas instituições é relevante. No Brasil grande parte dos cuidados pós-agudo e de pacientes crônicos é realizado no domicílio através da Atenção Domiciliar (AD).

OBJETIVO: O estudo visa avaliar a incidência de COVID-19 em pacientes em Atenção Domiciliar e o desfecho clínico destes pacientes; objetiva avaliar o impacto da epidemia sobre número de pacientes totais, novas admissões e hospitalizações.

MÉTODOs: Estudo descritivo dos casos de COVID-19 que acometeram população em atendimento pela Home Doctor (empresa privada de Atenção Domiciliar), entre os meses de março de 2020 a maio de 2020 e análise do número total de pacientes, da taxa de hospitalização e óbito no período comparado o período pré-epidemia.

RESULTADOS: Ocorreram 31 casos confirmados de COVID-19, sendo 21 sexo masculino, idade média 73 anos. Todos os pacientes apresentavam múltiplas comorbidades, sendo as mais prevalentes: Hipertensão Arterial Sistêmica (54\%) e Acidente Vascular Cerebral (35\%). A incidência de COVID-19 foi de 1\% na população estudada. Ocorreram 10 hospitalizações com 5 óbitos hospitalares e um caso de óbito domiciliar (letalidade 19\%). A segurança do atendimento foi mantida, com baixa taxa de óbito (0,6\%) e hospitalização (6,1\%).

CONCLUSÃO: A Atenção Domiciliar é capaz de manter atendimento seguro durante a pandemia por COVID-19, com baixa incidência de COVID-19, baixa taxa de hospitalização e baixa mortalidade quando comparada a instituições de longa permanência.

\section{REFERENCES}

1. COVID-19 Dashboard by Center for System Science and Engineering (CSSE) at Jonh Hopkins University (JHU). Acessado on line em 31/05/2020. https:// gisanddata.maps.arcgis.com/apps/opsdashboard/index.html.

2. Grabowski DC, Mor V. Nursing Home Care in Crisis in the Wake of COVID19. JAMA. Published online May 22, 2020. doi:10.1001/jama.2020.8524

3. Fiorentino G, Sebastião B, Mattos L, Grass K. Tendências do Setor da Saúde Acessado online em 19/06/2020. https://www.bain.com/contentassets/ de6f9f216c1e4ec39ad64590a8dd701b/healthcare-trends-in-brazil_por2.pdf

4. Dados acessados nos sites http://cnes.datasus.gov.br/; https://sisab.saude. gov.br/ e fornecidos pela CGAHD/DAHU-Min. da Saúde.

5. Wang H, Li T, Barbarino P, Gauthier S, Brodaty H, Molinuevo JL, et al. Dementia care during COVID-19. Lancet 2020, March 30 (epub ahead of print). doi: 10.1016/S0140-6736(20)30755-8

6. Lansbury LE, Brown CS, Nguyen-Van-Tam JS. Influenza in long-term care facilities. Influenza Other Resp Viruses 2017;11(5): 356-366. doil: 10.1111/ irv.12464
7. McMichael TM, Currie DW, Clark S, Pojosjans S, Kay M, Schwartz NG, et al. Epidemiology of COVID-19 in a long-term care facility in King Country, Washington. N Engl J Med 2020, Mar 272020 (epub ahead of print). doi: 10.1056/NEJMoa2005412

8. Herrera-Comas A, Zalakain J, Litwin C, Hsu AT, Lane N, Fernandez JL. Mortality associated with COVID-19 outbreaks in care homes: early international evidence. Acessado online em 16/06/202. https://ltccovid.org/2020/04/12/ mortality-associated-with-COVID-19-outbreaks-in-care-homes-early-international-evidence

9. Cuxart Mèlich A, Estrada Cuxart O. Hospital at Home: An Opportunity for Change. Med Clin (Barc) 2012 Apr 7;138(8):355-60.

10. McGoldrick, Mary MS, RN, CRNI Personal Protective Equipment Removal, Home Healthcare Now: May/June 2020 - Volume 38 - Issue 3 - p 170-171 doi: $10.1097 / \mathrm{NHH} .0000000000000879$

11. Ramon Martınez Riera J, Gras-Nieto E. Home care and COVID-19. before, in and after the state of alarm. Enfermeria Clinica (2020), doi: https://doi. org/10.1016/j.enfcli.2020.05.003 